\title{
ISSR analysis points to relict character of Aconitum bucovinense Zapał. (Ranunculaceae) at the range margin
}

\author{
Piotr Boroń', Joanna Zalewska-Gałosz', Agnieszka Sutkowska², Bogdan Zemanek', Józef Mitka* \\ ${ }^{1}$ Institute of Botany, Jagiellonian University, Kopernika 27, 31-501 Kraków, Poland \\ ${ }^{2}$ Department of Plant Breeding and Seed Science, Agricultural University, Łobzowska 24, 31-140 Kraków, Poland
}

\section{Abstract}

Aconitum bucovinense, a high-mountain species endemic to the Eastern and Southern Carpathians, including the Apuseni Mountains, is legally protected and classified in the Polish Red Data Book of Plants. It attains its NW geographical range in two peripheral populations in the Western Bieszczady Mountains (Polish Eastern Carpathians), isolated by a distance of $13.1 \mathrm{~km}$. PCR-ISSR analysis has been used to elucidate the within- and among-populational levels of species genetic diversity. A UPGMA and block clustering showed discreteness of the populations and subpopulations based on ISSR banding pattern. Analysis of Molecular Variance (AMOVA) revealed significant divergence $(P=0.024)$ of the two marginal populations and highly significant $(P<0.001)$ differentiation of subpopulations within populations. The theta index calculated for the two marginal populations and the core population in the Carpathians was $0.131 \pm 0.030$ S.D. Most of the population-genetic diversity indices of the marginal populations were not different from those in the core area but the Shannon's and rarity indices were lower in the marginal populations. It seems that founder effect and subsequent genetic bottleneck resulted in a fine-scale population genetic structure. The marginal populations under study need a relevant recovery program to maintain their genetic diversity.

Keywords: Carpathian Mountains, conservation genetics, endemic species, marginal populations, schizoendemism

\section{Introduction}

Previous phenetic studies on the variability of Aconitum bucovinense Zapał. (Bucovina's monkshood, Ranunculaceae) in the Eastern Carpathians showed morphological differences of the Bieszczady's populations against those located deeper in the Eastern Carpathians [1]. The presumed phenetic and genetic distinctness of the Bieszczady's populations could be interpreted in historical-biogeographical terms as an example of a schizoendemism (endemovicarism), i.e. continuous diversification of an ancestral taxon into derived taxa of identical chromosome numbers in various parts of the range [2]. It accepts the possibility of a parallel, independent origin of the close, low systematic units (e.g. geographic race or subspecies and biotype) in long-term isolated regions from a common, previously widely distributed, ancestral form. In the isolated regions, new forms arise, and the region of their occurrence are centers of neo-endemism, as for example the eastern Iberian peninsula and the Balearic islands [3]. The Eastern Carpathians

*Corresponding author. Email: j.mitka@uj.edu.pl

This is an Open Access digital version of the article distributed under the terms of the Creative Commons Attribution 3.0 License (creativecommons.org/licenses/by/3.0/), which permits redistribution, commercial and non-commercial, provided that the article is properly cited. represent one of the centers of the neo-endemism [4], and the Bieszczady Mountains are of special importance because of they are situated at the geographical border between the Eastern and Western Carpathians [5]. Twenty nine the Eastern/ Southern Carpathian species reach their geographical limits here, in these Aconitum bucovinense Zapał. [6]. This species is confined to the alpine and subalpine zones in the main ranges of the Eastern and Southern Carpathians with only two extant localities in Poland (Fig. 1, Fig. 2). As with most peripheral populations, it can be found in local patches of favorable environment [7], which are isolated from each other and limited in the area studied.

In the present paper we report the results of studies on two peripheral populations of Aconitum bucovinense by means of PCR-ISSR fingerprinting. Archibald et al. [8] stressed that ISSR markers are most useful for detecting if the clusters have at least one of a combination of attributes, including small population size, isolated distribution, self-compatibility, and heterozygote deficiency at allozyme loci. The ISSR technique is relatively fast, cheap and reproducible. They do not require genome sequence information and leads to multilocus and highly polymorphous patterns suitable for reliable estimation of the genetic variability at the population level, e.g. $[9,10]$. Recently it has been also used for phylogenetic analyses involving species that are closely related and represent recent radiations at the population level $[8,11-13]$, clonal diversity [14] and conservation concern (e.g. [15]). In addition to the information about population genetic diversity, ISSR markers seem provide relevant information for identifying the spatial 


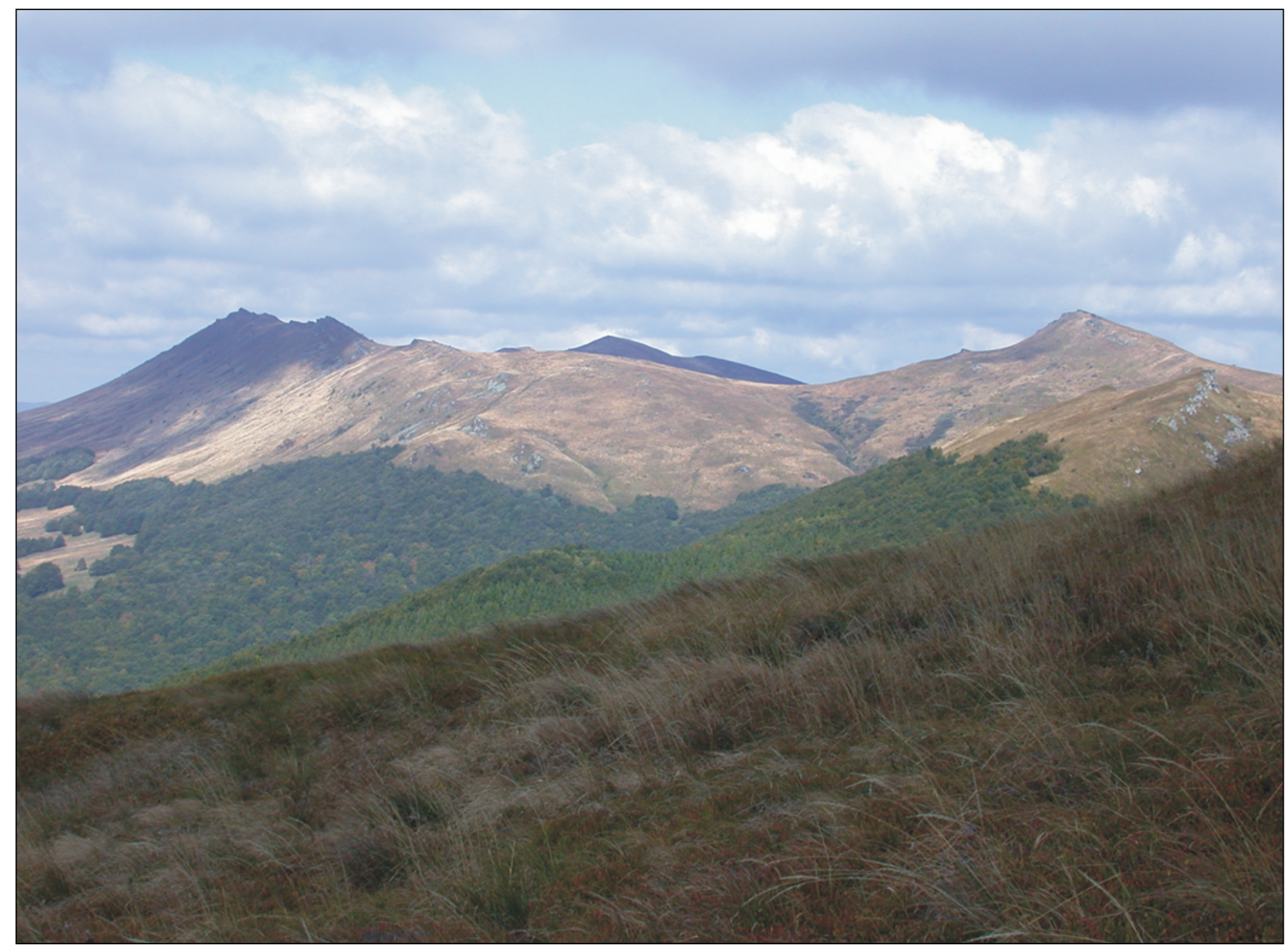

Fig. 1 Locality of Aconitum bucovinens on a local ridge (on the right in front) situated at the S slope of Halicz Mt, W Bieszczady Mts, Eastern Carpathians. In foreground Kopa Bukowska Mt (on the right) and Krzemień ridge (on the left). Open areas above artificially lowered tree-line in the E Carpathians are formed with tall-grass communities (Połoninas) consist of Deschampsia caespitosa L. (P. Beauv.) and Calamagrostis arundinacea (L.) Roth (in front). Photo by J. Mitka (2006.09.22).

scales and the genetic processes that take place in the populations [16] and are a suitable alternative to isozymes, especially in cases involving rare or clonal species that typically express low levels of variation, a case found in the present study.

Our specific emphasis was given to within- and amongpopulational genetic variation of Aconitum bucovinense at the edge of its range. The general prediction is that geographically peripheral populations should exhibit lower diversity and higher differentiation in comparison to the core area [17]. Such information will aide in understanding the microevolutionary processes typical for peripheral populations and elaborate recovery guidelines in face of the threats. The only two existant, peripheral populations in the Western Bieszczady Mts (WBM), Poland, have altogether $<150$ individuals, and according to population-genetic theory are prone to processes typical for small populations: genetic drift and inbreeding leading to genetic erosion, and likely extinction from random environmental fluctuations [18-21]. The two populations differ threefold in population size, and both have the clear sub-population spatial structure. From theoretical predictions and a number of empirical studies, the small populations might be expected to show reduced levels of polymorphism and allelic richness [22]. The small population, even genetically depauperized, may possesses private molecular markers. Alternatively, it can be only a subset of the larger population. Thus, we addressed the following questions: $(i)$ do the two peripheral populations differ from each other, (ii) does the smaller population form a subset of the larger population, (iii) is it a sub-population genetic structure within the populations? The general (iv) question is what conservation measures should be recommended to preserve the genetic integrity and diversity of the marginal populations?

\section{Material and methods}

\section{Study area}

The NW limit of the geographical distribution of Aconitum bucovinense is in the Western Bieszczady Mts (WBM) [23]. It is a mountain range of moderate heights (Mt Tarnica $1346 \mathrm{~m}$ ), situated in south-eastern Poland close to Slovakia and Ukraine (Fig. 1, Fig. 2). This is the only part of the Eastern Carpathians within the borders of Poland [24]. The WBM is protected within trans-boundary, trilateral Biosphere Reserve the Eastern Carpathians. They form one of the Carpathian "hot spots" with valuable fauna (large mammals), flora and vegetation [24].

The WBM are a part of the Eastern Beskids Mountains, known as "Waldenkarpaten" [25], forming the most westerly wing. This mountain range is a strong barrier to at least 


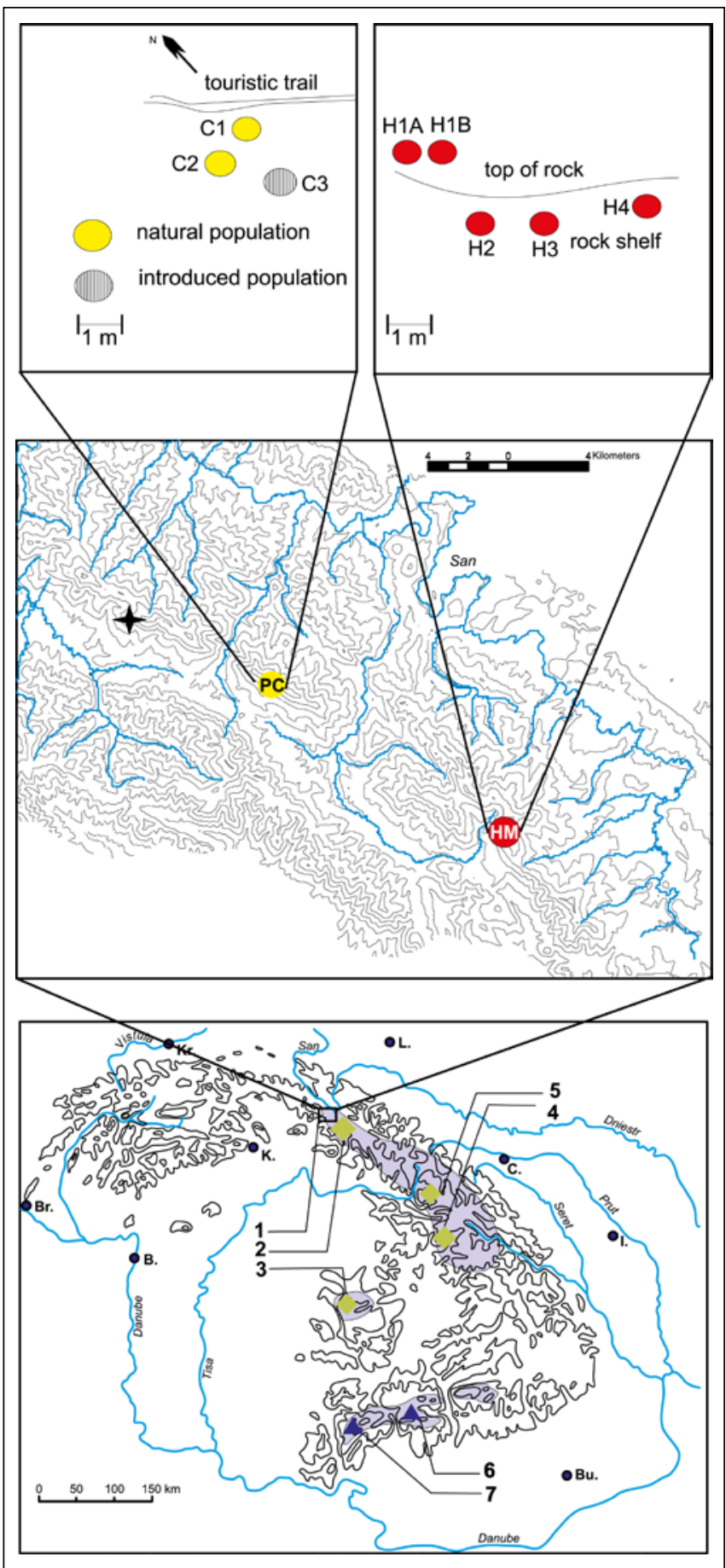

Fig. 2 Generalized distribution of Aconitum bucovinense (shaded area) and localities of sampled populations or OTUs. 1 - Western Bieszczady; 2 - Eastern Bieszczady; 3 - Bihor; 4 - Rodna; 5 - Giumalau-Rarau; 6 - Fogaraš; 7 - Retezat (see Tab. 1). $\mathrm{Br}$ - Bratislava; Bu - Bucureşti; B - Budapest; C - Černivce; I - Iasy; K - Košice; Kr - Kraków; L - Lviv. Locality of populations and subpopulations in the Western Bieszczady Mountains: HM - Halicz Mount; PC - Połonina Caryńska; asterix - vanished population on Hnatowe Berdo Mt.

postglacial migrations of many mountain plant species from the Eastern Carpathians towards Western Carpathians, as evidenced by the distribution of cytotypes, molecular variants and morphological-anatomical studies, e.g. [26-29]. The barriers and resulting phytogeographical divisions were first recognized and described by plant biogeographers (reviewed by Zemanek [5]). It can be argued that in the case of some alpine/subalpine species, including A. bucovinense, the Quaternary interglacial periods of warming could divide their more or less continuous distribution into several isolated ranges, now of the relict character. The alpine species in the WBM are linked with relict outcrops on the ridges and questas determined by lithological properties (Fig. 1).

\section{Species and populations}

Aconitum bucovinense is a rare, herbaceous perennial that is under strict legal protection and classified in the Polish Red Data Book of Plants and in the Vascular Plants of Red Data Book of the Polish Carpathians as a threatened species with VU category [30]. It is an endemic species to the Eastern and Southern Carpathians, including the Apuseni Mountains (see Fig. 2 and [31]) and an alpine-subalpine species, presumably with its center of occurrence in the inner Eastern Carpathians: the Rodna, Maramureş and Bistricei Mountains.

Its taxonomical status was recently clarified [31-34] and the cytogenetic studies showed that it is a stabilized tetraploid with presumably two genomes [35]. Field observations of visitors and the crossing data suggest that geitonogamy is the predominant breeding system of the species of Aconitum; sometimes floral damage is observed as an effect of pollen and nectar robbery by insects, mainly bumblebees (personal observation; see also [36,37]). Spatial isolation of the populations in the WBM (Fig. 2) suggests limited gene flow [38,39].

Preliminary observations made during the recovery program held within the plan for species protection in the Bieszczady National Park suggest that the factor limiting population development is seedling recruitment. No seedlings (excluding sown within a recovery program on Połonina Caryńska) were found at either location. In garden conditions seedlings of A. bucovinense germinated two years after sowing, and their mortality was more than $80 \%$.

The population at Połonina Caryńska (PC) was noted for the first time in [40]. It grows near to the touristic trail. In 1970 it's size was ca. 40 individuals. In the next 11 years (to 1981) it diminished to 22 individuals (herbarium collections were one of the threat factors). In the following 13 years, by the year 1994, its size again shrunk to 17 individuals, reaching a stable size with 5-6 flowering individuals in 2008. It covers ca. $7 \mathrm{~m}^{2}$ and grows in rock fissures covered by the Vaccinietum myrtilli association. The population consists of three subpopulations: C1, C2 and C3 (Fig. 2).

Subpopulation C3 was established within a recovery program under the auspice of the Bieszczady National Park in the years 2006-2008. The seeds were collected in 2005, germinated in garden conditions, and then 30 individuals reintroduced in situ in 2008. By 2009 twenty five of them (83\%) survived. Nowadays, the whole population at PC consists of 39 individuals, in this 8 in flowers (Tab. 1).

The second population, discovered in the 1990's, is situated on the south slope of Halicz Mt (HM; Fig. 1) on a local ridge in the Aconitum bucovinense-Festuca airoides-Saxifraga paniculata plant community in a distance from the tourist trail. It consists of 111 individuals, of which 14 were flowering (2008), and is distributed in four subpopulations H1-H4 on ca. $20 \mathrm{~m}^{2}$ (Tab. 1, Fig. 2). Its size has been stable for the last 15 years. The subpopulation on the top rock, $\mathrm{H} 1$, is much more isolated than the remaining ones.

In the WBM a third population on Mt Hnatowe Berdo existed (Fig. 2). It was found in 1994 and at that time 5 flowering individuals were counted on a square meter [23]. It was not found again, so it is probably became extinct. 
Tab. 1 Geographical location, subpopulation/population size, including non-flowering specimens and sampling size of Aconitum bucovinense in Western Bieszczady Mountains and in other Carpathian mountain ranges.

\begin{tabular}{lccccc}
\hline & & & & & \\
Region & Locality & subpopulation & (m a.s.l.) & N & size \\
WBM & PC & $1 / \mathrm{C} 1$ & 1220 & 8 & 8 \\
WBM & PC & $1 / \mathrm{C} 2$ & 1220 & 6 & 2 \\
WBM & PC & $1 / \mathrm{C} 3$ & 1220 & 25 & 8 \\
WBM & HM & $1 / \mathrm{H} 1$ & 1260 & 42 & 17 \\
WBM & HM & $1 / \mathrm{H} 2$ & 1260 & 54 & 17 \\
WBM & HM & $1 / \mathrm{H} 3$ & 1260 & 7 & 5 \\
WBM & HM & $1 / \mathrm{H} 4$ & 1260 & 8 & 5 \\
E Bieszczady & Pikuj & 2 & 1380 & $<250^{*}$ & 4 \\
Bihor & Cărligatele & 3 & 1550 & $<250^{*}$ & 5 \\
Giumalau-Rarău & Chiril & 4 & 920 & $<250^{*}$ & 3 \\
Chornogora & Sešul & 5 & 1440 & $<500^{*}$ & 1 \\
Fogaraš & Paltinului & 6 & 1980 & $<500^{*}$ & 3 \\
Retezat & Gura Zlata & 7 & 1820 & $<500^{*}$ & 3 \\
Retezat & Stanišoara & 7 & 1700 & $<500^{*}$ & 3 \\
\hline
\end{tabular}

HM - Mount Halicz; N - non-flowering specimens; PC - Połonina Caryńska; WBM - Western Bieszczady Mountains. * Population size estimated in proportion to habitat area.

\section{Sampling}

Individuals of Aconitum bucovinense were sampled from two populations in the WBM Mountains and from the localities scattered across the whole Carpathian range (Fig. 2), in 2003-2006 during field-trips to the region by one of the authors (JM). Fragments of leaves were stored in silica-gel. A leaf from the Chornogora Mts was taken from the herbarium material deposited in Krakow, Poland (KRA). WBM specimens with less than five leaves were not sampled.

\section{DNA extraction and ISSR survey}

Total genomic DNA was extracted from silica-gel-dried leaf fragments for each sample separately using modified CTAB method [41]. Thirty-fold diluted (20-100 ng/ $\mu$ l) DNA extracts were used as templates in DNA amplification. ISSR amplification was performed in $12.5 \mu \mathrm{l}$ reaction volume containing $1.25 \mu \mathrm{l}$ of 10 -fold concentrated reaction buffer $(500 \mathrm{mM}$ Tris- $\mathrm{HCl}$ pH 8.9, $500 \mathrm{mM} \mathrm{KCl,} 15$ mM MgCl - Kucharczyk TE), $0.25 \mu \mathrm{MgCl}_{2}$ (25 Mm - Fermentas), $0.25 \mu \mathrm{dNTP}$ mix (10 mM each - Invitrogen), $0.5 \mu \mathrm{l} \mathrm{Taq} \mathrm{DNA} \mathrm{polymerase}$ $(2 \mathrm{u} / \mathrm{l}-$ Kucharczyk TE) and $2 \mu \mathrm{l}$ of ISSR primer (10 mM - Integrated DNA Technologies). Reaction was run in Mastercycler Gradient (Eppendorf) with following conditions: $94^{\circ} \mathrm{C}$ for
5 minutes - initial denaturation, 35 cycles with: $94^{\circ} \mathrm{C}$ for 35 seconds - denaturation, $43^{\circ} \mathrm{C}$ (primers ISSR2, ISSR4, ISSR7) or $47^{\circ} \mathrm{C}$ (primers ISSR1, ISSR6) for 40 seconds - primer annealing and $72^{\circ} \mathrm{C}$ for 35 seconds - primer extension followed by $72^{\circ} \mathrm{C}$ for 7 minutes of final extention. Full primer sequences are listed in Tab. 2. ISSR amplification products and molecular weight marker (100 bp ruler) were separated in $1 \%$ agarose gel containing ethidium bromide $(0.5 \mu \mathrm{g} / \mathrm{ml})$, visualized in ultraviolet light and photographed.

For analysis of band patterns GelScan ver. 1.45 (Kucharczyk Techniki Elektroforetyczne) sofware was used. Thanks to the opportunity to create a calibration curve based on the band pattern of markers length (GeneRuler TM 100 bp - Fermentas), it was possible to determine the molecular weight of the resulting amplification products. With the application of a manual checking function, PCR products sizes were precisely determined (within the customary error borders).

\section{ISSR data analyses}

The amplification products were scored as a presence/ absence matrix of binary data. The matrix, after removing single and non-interpretable products encompassed 258 ISSR bands found in 84 Aconitum bucovinense samples (Tab. 1). The resulting binary data were analysed using POPGENE ver. 1.32 [42]. Genetic diversity within and among populations were measured by the percentage of polymorphic bands $(P L P)$, the effective number of alleles $\left(n_{\mathrm{e}}\right)$, observed number of alleles $\left(n_{\mathrm{a}}\right)$, Nei's [43] gene diversity or expected heterozygosity $\left(H_{\mathrm{e}}\right)$ and Shannon's index $(I)$. Additionally, rarity index corresponding to "frequency-down-weighted marker values" per population was calculated [44] and its statistical significance based on 1000 permutation was assessed. $R$ scripts to calculate $D W$ permutation test are available from AFLPdat software [45].

Then, the block structure of the ISSR data was revealed including the following steps: data normalization to unit length, detection of outliers, selection of clustering method, checking within-group diversity, analyzing of the resulting block structure of data, rearrangement of samples and bands within the groups and finally the selection of the informative bands [46]. In the effect the ISSR data set was reduced to 67 the most informative bands using the weighting algorithm based on the sum of the F statistics [47]. To produce a sample resemblance matrix, the van der Maarel's distances, and to produce a band resemblance matrix, the Euclidean distances were calculated. Both matrices were used in a minimum variance clustering (Ward's clustering, [48]) to classify samples and bands. A correspondence analysis was carried out to rearrange samples and bands within groups [49]. All the calculations were carried out with MULVA-5 software [50].

Genetic dissimilarities (distances) were calculated using the transformed formula ([51], $D=1-$ Nei coefficient) based on

Tab. 2 Primers used in ISSR analysis and banding characteristics in samples of Aconitum bucovinense.

\begin{tabular}{|c|c|c|c|c|c|c|}
\hline Primer & Size $(\mathrm{pb})$ & Sequence $5^{\prime}-3^{\prime}$ & No. of bands & Max. & Mean & Median \\
\hline ISSR 1 & $270-1190$ & TCT СТC ТСТ СТС ТСТ СС & 332 & 22 & 6.3 & 4.0 \\
\hline ISSR 2 & $290-750$ & AGA GAG AGA GAG AGA GT & 498 & 44 & 11.1 & 6.0 \\
\hline ISSR 4 & $250-960$ & ATG ATG ATG ATG ATG ATG & 407 & 81 & 11.0 & 5.0 \\
\hline ISSR 6 & $230-1240$ & ACA CAC ACA CAC ACA CG & 311 & 18 & 5.0 & 4.0 \\
\hline ISSR 7 & $230-1350$ & ACA CAC ACA CAC ACA CT & 435 & 46 & 7.1 & 4.0 \\
\hline
\end{tabular}




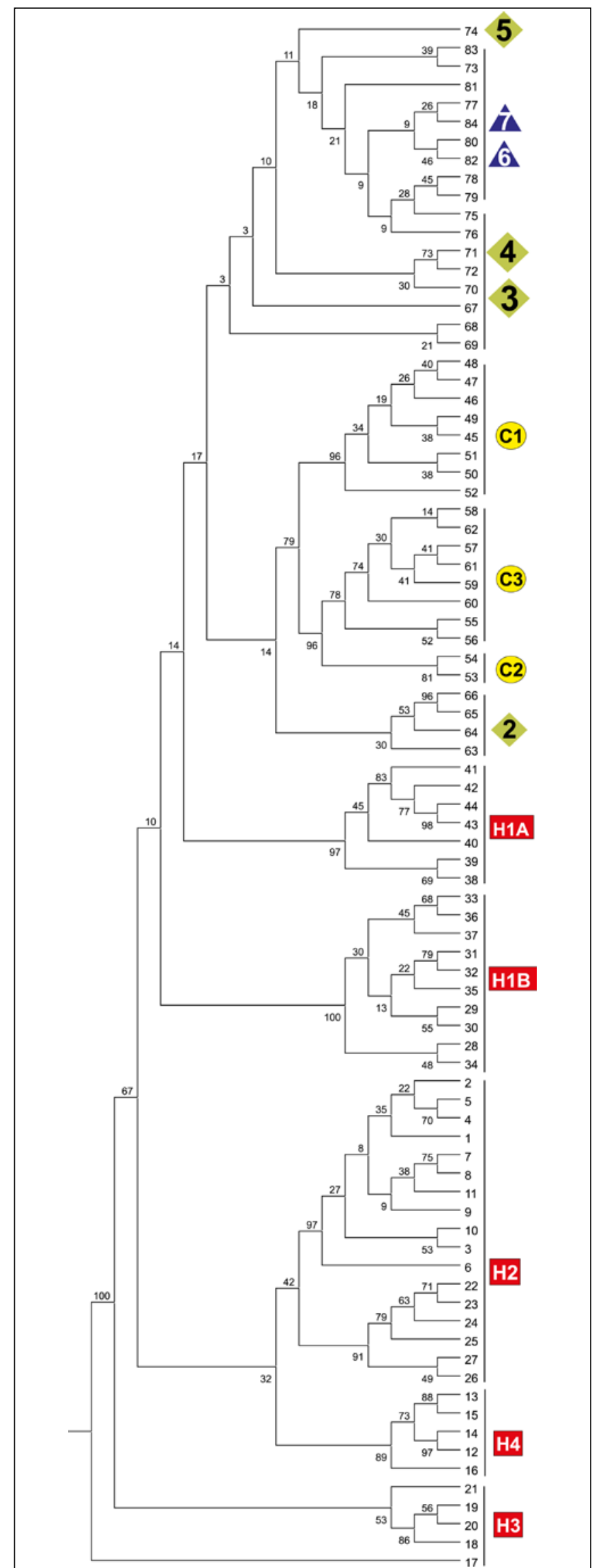

Fig. 3 UPGMA clustering based on the reduced set of ISSR bands of Aconitum bucovinense from the WBM and other mountain ranges in the Carpathians. C1-C3 - subpopulations on PC; H1-H4 - subpopulations on HM; 2-7 - samples from other Carpathian mountain ranges (see Fig. 2 and Tab. 1). HM - Halicz Mount; PC - Połonina Caryńska; WBM - Western Bieszczady Mountains.
67 bands. The DISTANCE procedure based on 1000 bootstrap iterations was applied using PhylTools software [52]. The trees were obtained with the use of the ultrametric UPGMA clustering method implemented in the PHYLIP package [53]. Relative bootstrap support values were computed with the CONSENSE option in the PHYLIP package. The OUTREE file was drawn with MEGA4 software [54].

Analysis of molecular variance (AMOVA) was carried out using ARLEQUIN software version 3.1 [55,56]. Variance components were defined between two peripheral WBM populations and among subpopulations within the two populations. Significance of the group portioning was tested against alternative random distribution (null hypothesis) through 1000 permutations of individuals among groups, what is analogous to Fisher's exact test [57]. Additionally, theta index, equivalent to $F_{\text {st }}$ [58], and its confidence interval based on the jackknifing over loci (to obtain variance estimate), and bootstrapping over loci was calculated using a TFPGA software [59].

\section{Results}

A UPGMA clustering based on the ISSR band pattern points to substantial differences between PC and HM populations (Fig. 3). Each of the $\mathrm{H}$ and $\mathrm{C}$ subpopulations could be distinguished on the basis of a specific combination of band pattern (Tab. 3), and subpopulation $\mathrm{H} 1$ was additionally internally diversified into clusters $\mathrm{H} 1 \mathrm{~A}$ and $\mathrm{H} 1 \mathrm{~B}$ with a strong 97 and $100 \%$ support. Internally diversified was also the subpopulation $\mathrm{H} 2$, however with a weak $42 \%$ support. The four samples from Mt Pikuj (2), the neighbour population in the Eastern Bieszczady Mts, joined the C1-C3 subpopulations, however with a weak $14 \%$ support. The remaining samples from the Eastern and Southern Carpathians formed weakly supported, internally diversified and sister cluster to the Bieszczady's populations (Fig. 3).

The numerical analysis with the use of the multivariate algorithms enabled the block structure of samples and bands to be uncover (Tab. 3). Some of the bands were characteristic only for the particular subpopulation, as for example ISSR18, 46 for the subpopulation C3 or ISSR7-254 for H1B or had optimum in the one, two or more subpopulations, as for example ISSR1-31 in the Eastern and Southern Carpathians, ISSR2-72 in the H3 and H4 or ISSR7-244 in C and H1B. The most conspicuous was ISSR4-105, common for most of the Southern-Eastern Carpathian populations and present in a part of the H2. The most common was ISSR4-98, however absent in the $\mathrm{H} 1 \mathrm{~A}$. Internal diversification of the $\mathrm{H} 2$ subpopulation was supported by some bands, for example by absence of ISSR2-58 and ISS4-105 or presence of ISSR7-224. ISSR2-89 connected Mt Pikuj (the E Bieszczady Mts) with C3 and H4, ISSR4-103 with $\mathrm{C}$, and ISSR6-181 with $\mathrm{H} 3$.

In the AMOVA, the difference in genetic structuring of the two peripheral populations was statistically significant $(P=0.024$; Tab. 4). In PC relatively less molecular variation was attributable to individuals within subpopulations (52.73\%), in comparison to HM, where the value reached $69.28 \%$ of the total molecular variability. The differences between the subpopulations in the two peripheral populations in the WBM were statistically significant $(P<0.001)$ and account for $29 \%$ of the total variance. On PC the among-subpopulational component of the variance reached $47.27 \%$ and on $\mathrm{H}-30.72 \%$. The theta statistics among the two marginal populations and 


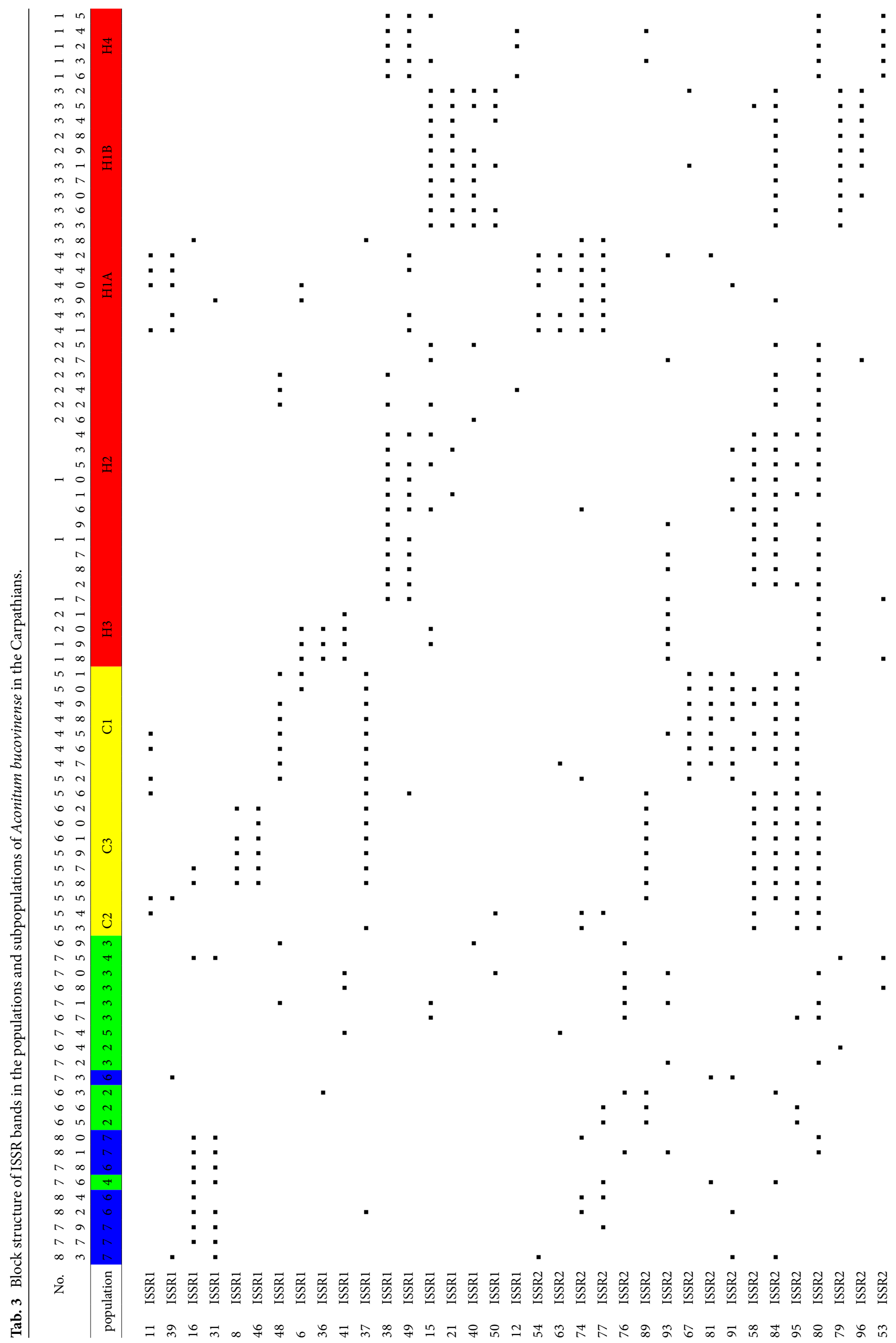




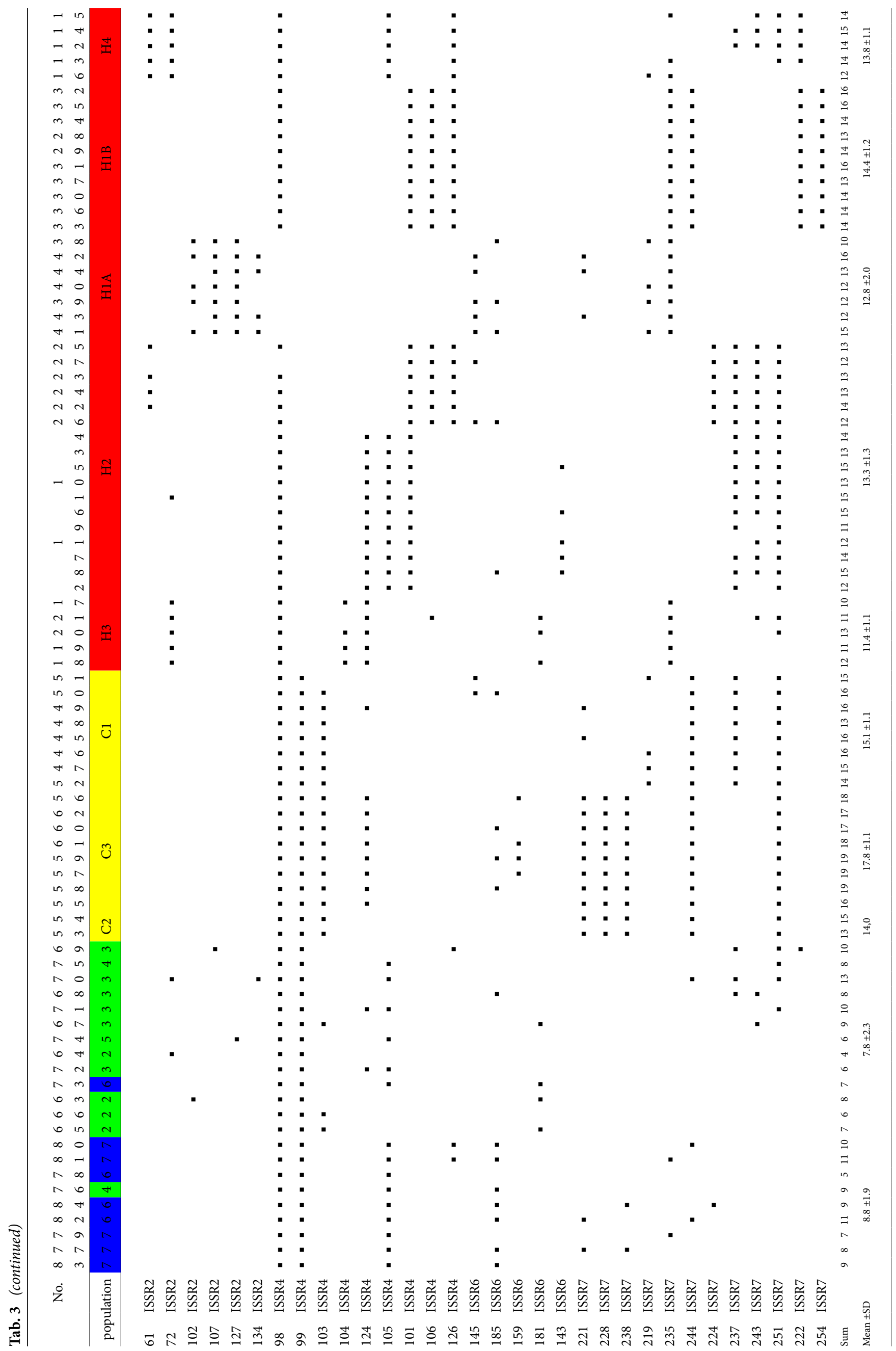


the remaining, core population in the E and S Carpathians equaled to 0.131 and its $95 \%$ confidence interval was within $0.080-0.193$. Among the genetic-population indices (Tab. 5) the Shannon's index $I$ and the rarity index $D W$ were higher in the core area then in the marginal populations. The remaining indices, especially $H_{\mathrm{e}}$, did not differentiate among the populations compared.

\section{Discussion}

The molecular ISSR analysis pointed to the genetic distinctness of neighbouring populations of Aconitum bucovinense in the WBM. The known closest population in Mt Pikuj (E Bieszczady Mts), located ca. 35 kilometers away [23], displayed some genetic ISSR similarity with the Bieszczady's populations. Both of WBM's populations differed not only from each other, but there was also a conspicuous difference in within-populational variability of the species. Its internal diversification is clearly seen in block structure of ISSR bands, where each of the subpopulations is clearly defined by the characteristic bands (Tab. 3), seen in the UPGMA clustering (Fig. 3), and AMOVA analysis (Tab. 4). Thus, we can suppose that the specific mating system linked with the presumably long-term spatial isolation of the two the marginal populations were sufficient to accumulate some differentiation not only between the populations but also among subpopulations in the WBM. It could be linked with within-patch ecological Allee effects as a result of pollen limitation in low-density or isolated patches. Both germination rate and offspring survival were lower for seeds produced in low-density patches of $A$. napellus in northern France [60]. Also, significant genetic structure at small distances is to be found at some plant species due to restricted seed dispersal leading to limited seedling recruitment around the maternal plant (for discussion see [61]). For example, in Delphinium nutallianum Pritzel, a species with similar reproductive biology, spatial autocorrelations at the scale of a few $\mathrm{cm}$ to $\mathrm{m}$ calculated for several allozyme loci showed genetic differentiation among distant populations not different from that among subpopulations 5-20 m apart. The overall genetic variance among individuals was mostly determined by fixation within the smallest spatial scale of $\mathrm{cm}$ to $\mathrm{m}$ [38]. According to authors, it could be the result of the postpollination selection that may further modify genetic structure during the life cycle leading to transient local kin structure that is regenerated during every episode of seedling recruitment. An opposite opinion has also been expressed, that perhaps the directional, e.g. selection against homozygous rare alleles, is less possible because stochastic or demographic factors, often combined with habitat destruction, have most certainly played a significant part in the reduction of genetic variation or are of more immediate importance than population genetics $[62,63]$ (critically reviewed in $[64]$ ).

Another factor could be inbreeding, as for example in $A$. lycoctonum studied across Europe. The investigations show inbreeding in more than half the populations under study [65]. It resulted in the deficiency of heterozygotes. It can be a result of geitonogamy and pollen robery [36,37]. In patches, where floral density is low, the frequency of self-fertilization or pollination between closely related genotypes may increase, thereby reducing seed production as a consequence of partial self-incompatibility or inbreeding depression, or seed quality as a consequence of inbreeding depression [60]. Generally inbreeding, either as a result of mating among close relatives in small populations or as a result of selfing, would tend to fix morphological differences among populations [66,67], lowers genetic variation and facilitates genetic drift in species that are normally highly outbred $[68,69]$. The increased level of inbreeding in small populations in combination with inbreeding depression may have contributed to their fitness reduction, i.e. "genetic erosion" [70].

In spite of the general genetic impoverishment of small populations, on PC the population possesses private markers, as for example ISSR1-8, and 46 or ISSR7-228. The data obtained do not allow to give a conclusive answer to the question. In the dispersalistic "stepping stone" model, the repeated founding of a small population would likely have resulted in the stochastic loss of genetic variation, mainly rare alleles $[22,71]$. ISSR analysis does not solve the problem: most bands are common for HM and PC or some of them are absent in the larger HM population, as for example ISSR4-99 (Tab. 3).

None of the individuals from the marginal populations intermingled in UPGMA clusters, nevertheless many ISSR bands were common for the both populations. It seems that the number of private bands was sufficient to make the withinpopulational structuring of both populations statistically significant $(P<0.001)$. In the effect $15.29 \%(P=0.024)$ of the molecular variance could be attributable to the differences between the populations in the WBM. The molecular variance among subpopulations within populations in the WBM was

Tab. 4 Analysis of molecular variance (AMOVA) of Aconitum bucovinense in the W Bieszczady (E Carpathians, Poland).

\begin{tabular}{|c|c|c|c|c|c|c|}
\hline & Source of variation & d.f. & SS & Variance components & Percentage of variation & $P$-value \\
\hline \multirow[t]{2}{*}{ A. } & HM - among subpopulations & 3 & 196.867 & 5.241 & 30.720 & $<0.001$ \\
\hline & Among individuals within subpopulations & 41 & 484.555 & 11.818 & 69.280 & $<0.001$ \\
\hline \multirow[t]{2}{*}{ B. } & PC - among subpopulations & 2 & 88.373 & 6.569 & 47.270 & $<0.001$ \\
\hline & Among individuals within subpopulations & 15 & 109.905 & 7.327 & 52.730 & $<0.001$ \\
\hline \multirow[t]{3}{*}{ C. } & WBM - among populations & 1 & 134.681 & 2.913 & 15.290 & 0.024 \\
\hline & Among subpopulations within populations & 5 & 285.240 & 5.525 & 29.000 & $<0.001$ \\
\hline & Among individuals within subpopulations & 56 & 594.460 & 10.615 & 55.710 & $<0.001$ \\
\hline
\end{tabular}

HM - Halicz Mt; PC - Połonina Caryńska; WBM - W Bieszczady Mts. 
Tab. 5 Genetic diversity within populations and subpopulations of Aconitum bucovinense based on 258 ISSR bands (loci).

\begin{tabular}{|c|c|c|c|c|c|c|c|c|}
\hline Population & $n$ & $P L P(\%)$ & $H_{e}$ & $n_{\mathrm{a}}$ & $n_{\mathrm{e}}$ & $I$ & $D W$ & Rsign \\
\hline $1 / \mathrm{PC} 1$ & 8 & 23.6 & 0.0502 & 1.2054 & 1.0734 & 0.0822 & 2.45886 & ns \\
\hline $1 / \mathrm{PC} 2$ & 3 & 12.8 & 0.0247 & 1.0415 & 1.0415 & 0.0369 & 2.49221 & ns \\
\hline 1/PC3 & 8 & 19.8 & 0.0711 & 1.3256 & 1.1096 & 0.1170 & 2.63456 & ns \\
\hline PC total & 19 & 50.0 & 0.0746 & 1.5000 & 1.0450 & 0.1321 & 2.55487 & small \\
\hline 1/HM1 & 17 & 29.1 & 0.0831 & 1.4225 & 1.1224 & 0.1395 & 2.97267 & ns \\
\hline 1/HM2 & 17 & 21.3 & 0.0575 & 1.3411 & 1.0813 & 0.0999 & 2.12293 & small \\
\hline 1/HM3 & 5 & 18.6 & 0.0423 & 1.1628 & 1.0626 & 0.0686 & 2.26828 & ns \\
\hline 1/HM4 & 5 & 14.7 & 0.0325 & 1.1124 & 1.0501 & 0.0513 & 2.10847 & small \\
\hline HM total & 44 & 69.77 & 0.0800 & 1.6977 & 1.0790 & 0.1476 & 2.46171 & small \\
\hline $\mathrm{EC}(2)$ & 4 & 30.6 & 0.0819 & 1.2984 & 1.1249 & 0.1307 & 4.42738 & large \\
\hline $\mathrm{EC}(3+4+5)$ & 8 & 48.8 & 0.0876 & 1.4806 & 1.1147 & 0.1543 & 4.37728 & large \\
\hline SC $(6+7)$ & 7 & 30.2 & 0.0647 & 1.2868 & 1.0898 & 0.1087 & 3.21438 & $\mathrm{~ns}$ \\
\hline $\mathrm{EC}+\mathrm{SC}$ & 19 & 68.60 & 0.0864 & 1.6860 & 1.1069 & 0.1635 & 4.02093 & large \\
\hline
\end{tabular}

$D W$ - rarity index corresponding to "frequency-down-weighted marker values" per population [44]; EC - Eastern Carpathians; $H_{\mathrm{e}}-\mathrm{Nei}$ 's [43] gene diversity, with $F_{\text {is }}$ assumed to be 0.2 (see [65]); HM - Mount Halicz; I - Shannon's information index; $n$ - sampling size; $n_{\mathrm{a}}$ - observed No. of alleles; $n_{\mathrm{e}}$ - effective No. of alleles; ns - no significant; PC - Połonina Caryńska; PLP - percentage of polymorphic loci; Rsign - significance of rarity index $(P \leq 0.05)$ based on 1000 permutations [45]; SC - Southern Carpathians. See also Tab. 1.

also high and amounted $29.00 \%(P<0.001)$, proving the distinctness of even the particular subpopulations within the peripheral populations of A. bucovinense (Tab. 3). The theta index $0.131 \pm 0.030$ S.D. points to moderate genetic differentiation among the two margin and core populations of Aconitum bucovinense in the Carpathians. According to Reynolds et al. [72] the derivation of theta index assumes that genetic divergence among the groups is due to only drift and it measures divergence on a short evolutionary time scale. Previous phenetic studies [1] showed the morphological coherence of the Bieszczady's population and its differentiation against the remaining Eastern-Carpathian populations. The morphological distinctness (seen on the indumentum and in shape of the spur) was discussed in terms of the schizoendemism. The present results of PCR-ISSR analysis persuade that the phenetic differences found at the edge of the geographical distribution of the species may have some genetic background in the effect of genetic drift, neutral mutagenesis or response to local selective forces. The loss of genetic diversity in the marginal populations (Shannon's and rarity indices) and, in the same time, the existence of private markers advocates for genetic drift accompanied by the presumably reduced of the number of alleles per locus [73].

An experimental cross-pollination between the HM and PC populations may shed some light on the problem. The study should be carried out to determine if seed production and seedling survival is any higher after the outcrossing. Also, reciprocal seed transplatantation experiments should be carried out to demonstrate local adaptations. Additionally, health condition and reproductive parameters of the newly established C3 subpopulation, linked with their adaptation to local conditions, should be assessed in the future. As Fahselt [74] noted, long-term monitoring of the newly established population is necessary because although initially transplant survival rates may be high they are often followed by remarkable reversals over time. Probably, it may concern also specimens obtained from the seedlings.

What protection measures should be recommended? In the long-term conservation concern genetic variation has been seen as a crucial to success in the management of rare and endangered species. In the short-term, given the limited number of individuals, it is necessary to protect all the existing populations [75]. It seems also feasible to establish a transplanted population of Aconitum bucovinense from seeds obtained from the population HM, which is the most genetically diversified. Conservation goal can be achieved by careful choice of the transplant site, taking into consideration the phytosociological criteria, in order to increase the number of conserved populations [76,77]. Additionally, the main ex situ conservation policy is maintenance of a germplasm bank [78]. The seeds of Aconitum bucovinense are stored in the Center for Biological Conservation of the Polish Academy of Sciences, Warsaw. Additionally, specimens obtained from seeds should be maintained in the botanical gardens.

The preservation population of the species was established in 2006 year in the experimental garden of the educationalscientific station of the Bieszczady National Park in Suche Rzeki. The cultivation of the species should be continued to ensure that there is a stock of individuals on hand for reintroduction.

\section{Acknowledgements}

The authors would like to thank Jacqueline Trojan (New Mexico State University) for linguistic corrections and to an anonymous reviewer for constructive comments. To Elżbieta and Leopold Bekier for their hospitality in Wołosate, the Western Bieszczady Mts. The work was supported by a MNiSzW grant No. 8144/B/P01/2011/40.

\section{References}

1. Mitka J. Phenetic and geographic pattern of Aconitum sect. Napellus (Ranunculaceae) in the Eastern Carpathians - a 
numerical approach. Acta Soc Bot Pol. 2002;71:35-48.

2. Richardson IBK. Endemic taxa and the taxonomist. In: Street H, editor. Essays in plant taxonomy. London: Academic Press; 1978. p. 245-262.

3. Rossello JA. Testing taxonomic and biogeographical relationships in a narrow Mediterranean endemic complex (Hippocrepis balearica) using RAPD markers. Ann Bot. 2002;89:321-327. http://dx.doi.org/10.1093/aob/mcf044

4. Pawłowski B. Remarques sur l'endemisme dans la flore des Alpes et des Carpates. Vegetatio. 1970;21:181-243. http:// dx.doi.org/10.1007/BF02269663

5. Zemanek B. The phytogeographical boundry between the East and West Carpathians - past and present. Thaiszia. 1991;1:59-67.

6. Zemanek B, Winnicki T. Rośliny naczyniowe Bieszczadzkiego Parku Narodowego. Ośrodek Naukowo-Dydaktyczny BdPN; 1999. (Monografie Bieszczadzkie; vol 3).

7. Brown JH, Stevens GC, Kaufman DM. The geographic range: size, shape, boundaries, and internal structure. Annu Rev Ecol Syst. 1996;27(1):597-623. http://dx.doi. org/10.1146/annurev.ecolsys.27.1.597

8. Archibald JK, Crawford DJ, Santos-Guerra A, Mort ME. The utility of automated analysis of inter-simple sequence repeat (ISSR) loci for resolving relationships in the Canary Island species of Tolpis (Asteraceae). Am J Bot. 2006;93(8):1154-1162. http://dx.doi.org/10.3732/ ajb.93.8.1154

9. Alexander JA, Liston A, Popovich SJ. Genetic diversity of the narrow endemic Astragalus oniciformis (Fabaceae). Am J Bot. 2004;91(12):2004-2012. http://dx.doi.org/10.3732/ ajb.91.12.2004

10. Tsumura Y, Ohba K, Strauss SH. Diversity and inheritance of inter-simple sequence repeat polymorphisms in Douglas-fir (Pseudotsuga menziesii) and sugi (Cryptomeria japonica). Theor Appl Genet. 1996;92:40-45. http://dx.doi. org/10.1007/BF00222949

11. Bussell JD, Waycott M, Chappill JA. Arbitrarily amplified DNA markers as characters for phylogenetic inference. Perspectives in Plant Ecology, Evolution and Systematics. 2005;7(1):3-26. http://dx.doi.org/10.1016/j. ppees.2004.07.001

12. Sutkowska A, Mitka J. Molecular PCR-ISSR analysis in Bromus subgenus Festucaria - preliminary results. In: Frey L, editor. Biology of grasses. Kraków: W. Szafer Institute of Botany, Polish Academy of Sciences; 2005. p. 1-10.

13. Mitka J, Sutkowska A, Ilnicki T, Joachimiak A. Reticulate evolution of high-alpine Aconitum (Ranunculaceae) in the Eastern Sudetes and Western Carpathians (Central Europe). Acta Biol Cracov Ser Bot. 2007;49(2):15-26.

14. Esselman EJ, Jianqiang L, Crawford DJ, Windus JL, Wolfe AD. Clonal diversity in the rare Calamagrostis porteri subsp. insperata (Poaceae): comparative results for allozyme and random amplified polymorhic DNA (RAPD) and intersimple sequence repeat (ISSR) markers. Mol Ecol. 1999;8:443451. http://dx.doi.org/10.1046/j.1365-294X.1999.00585.x

15. Camacho FJ, Liston A. Population structure and genetic diversity of Botrychium pumicola (Ophioglossaceae) based on inter-simple sequence repeats (ISSR). Am J Bot. 2001;88(6):1065-1070. http://dx.doi.org/10.2307/2657089

16. Heywood V. Plant conservation: old problems, new perspectives. Biol Conserv. 2003;113:321-335. http://dx.doi. org/10.1016/S0006-3207(03)00121-6

17. Sagarin RD, Gaines SD. The "abundant centre" distribution: to what extent is it a biogeographical rule? Ecol Lett. 2002;5:137-147. http://dx.doi. org/10.1046/j.1461-0248.2002.00297.x

18. Lande R, Schemske DW. The evolution of self-fertilization and inbreeding depression in plants. I. genetic models. Evolution. 1985;39(1):24-40. http://dx.doi. org/10.2307/2408514

19. Goodman D. The demography of chance extinction. In: Soulé ME, editor. Viable populations for conservation. Cambridge: Cambridge University Press; 1987. p. 11-34. http://dx.doi.org/10.1017/CBO9780511623400.003

20. Lesica P, Allendorf FW. Are small populations of plants worth preserving? Conserv Biol. 1992;6:135-139. http:// dx.doi.org/10.1046/j.1523-1739.1992.610135.x

21. Dolan RW. Patterns of isozyme variation in relation to population size, isolation, and phytogeographic history of royal catchfly (Silene regia; Caryophyllaceae). Am J Bot. 1994;81:965-972. http://dx.doi.org/10.2307/2445289

22. Chang C-S, Choi DY, Kim H, Park TY, Kim Y-S. Patterns of allozyme variation in relation to population size of the threatened plant Megaleranthis saniculifolia (Ranunculaceae) in Korea. J Plant Biol. 2005;48:339-350. http://dx.doi. org/10.1007/BF03030575

23. Mitka J, Zemanek B. Rare and threatened plant species of the Bieszczady National Park (Western Bieszczady, Eastern Carpathians). Roczniki Bieszczadzkie. 1997;5:19-41.

24. Winnicki T, Zemanek B. Nature in the Bieszczady National Park. Ustrzyki Dolne: Bieszczady National Park; 2003.

25. Pax F. Grundzüge der Pflanzenverbreitung in der Karpathen. Leipzig: Verlag von Wilhelm Enegelmann; 1898. (vol 1).

26. Konnert M, Bergmann F. The geographical distribution of genetic variation of silver fir (Abies alba, Pinaceae) in relation to its migration history. Plant Syst Evol. 1995;196:1930. http://dx.doi.org/10.1007/BF00985333

27. Boratyńska K, Muchewicz E. Pinus mugo Turra geographic differentiation based on needle characters. Dendrobiology. 2004;51:9-17.

28. Ronikier M, Cieślak E, Korbecka G. High genetic differentiation in the alpine plant Campanula alpina Jacq. (Campanulaceae): evidence for glacial survival in several Carpathian regions and long-term isolation between the Carpathians and the Alps. Mol Ecol. 2008;17:1763-1775. http://dx.doi.org/10.1111/j.1365-294X.2008.03664.x

29. Tešitel J, Malinová T, Štech M, Herbstová M. Variation in the Melampyrum sylvaticum group in the Carpathian and Hercynian region: two lineages with different evolutionary histories. Preslia. 2009;81:1-22.

30. Mitka J. Tojad bukowiński (T. niski) Aconitum bucovinense Zapał. In: Mirek Z, Piękoś-Mirkowa H, editors. Red data book of the Polish Carpathians, vascular plants. Kraków: W. Szafer Institute of Botany, Polish Academy of Sciences; 2008. p. 62-63.

31. Mitka J. Systematics of Aconitum subgen. Aconitum in the Eastern Carpathians - preliminary results. Roczniki Bieszczadzkie. 2000;9:79-116.

32. Seitz W. Die Taxonomie der Aconitum napellus-Gruppe in Europa. Feddes Repert. 1969;80(1):1-76. http://dx.doi. org/10.1002/fedr.19690800102

33. Starmühler W, Mitka J. Systematics and chorology of Aconitum sect. Napellus (Ranunculaceae) and its hybrids in the Northern Carpathians and Forest Carpathians. Thaiszia. 2001;10:115-136. 
34. Mitka J. The genus Aconitum L (Ranunculaceae) in Poland and adjacent countries. A phenetic-geographic study. Kraków: Institute of Botany of the Jagiellonian University; 2003.

35. Ilnicki T, Mitka J. Chromosome numbers on Aconitum sect. Aconitum (Ranunculaceae) from the Carpathians. Caryologia. 2009;62(3):198-203.

36. Utelli A-B, Roy BA. Pollinator abundance and behavior on Aconitum lycoctonum (Ranunculaceae): an analysis of the quantity and quality components of pollination. Oikos. 2000;89:461-470. http://dx.doi. org/10.1034/j.1600-0706.2000.890305.x

37. Utelli A-B, Roy BA. Causes and consequences of floral damage in Aconitum lycoctonum at high and low elevations in Switzerland. Oecologia. 2001;127:266-273. http://dx.doi. org/10.1007/s004420000580

38. Williams CF, Waser NM. Spatial genetic structure of Delphinium nuttallianum populations: inferences about gene flow. Heredity. 1999;83:541-550. http://dx.doi.org/10.1038/ sj.hdy. 6885920

39. Zhang D, Chen S, Chen S, Zhang D, Gao Q. Patterns of genetic variation in Swertia przewalskii, an endangered endemic species of the Qinghai-Tibet Plateau. Biochem Genet. 2007;45:33-50. http://dx.doi.org/10.1007/ s10528-006-9057-7

40. Jasiewicz A, Zarzycki K. Carex rupestris Bell ex All. and Aconitum tauricum Wulf . subsp nanum (Baumg.) Gáy., two new plants for the Polish flora from the West Bieszczady. Fragm Flor Geobot. 1959;2:24-27.

41. Gawel N, Jarret RL. Cytoplasmic genetic diversity in banana and plantain. Euphytica. 1991;52(1):19-23. http:// dx.doi.org/10.1007/BF00037852

42. Yeh F, Yang R, Boyle T. POPGENE version 1.32. Microsoftbased freeware for population genetic analysis. Canada: Molecular Biology and Biotechnology Center, University of Alberta; 1999.

43. Nei M. Analysis of gene diversity in subdivided populations. PNAS. 1973;70(12):3321-3323. http://dx.doi. org/10.1073/pnas.70.12.3321

44. Schönswetter P, Tribsch A. Vicariance and dispersal in the Alpine perennial Bupleurum stellatum L. (Apiaceae). Taxon. 2005;54:725. http://dx.doi.org/10.2307/25065429

45. Ehrich D. AFLPdat: a collection of $r$ functions for convenient handling of AFLP data. Mol Ecol Notes. 2006;6:603604. http://dx.doi.org/10.1111/j.1471-8286.2006.01380.x

46. Feoli E, Orlóci L. Analysis of concentration and detection of underlying factors in structured tables. Vegetatio. 1979;40:49-54. http://dx.doi.org/10.1007/BF00052015

47. Jancey RC. Species ordering on a variance criterion. Vegetatio. 1979;39(1):59-63. http://dx.doi.org/10.1007/ BF00055329

48. Ward JH. Hierarchical grouping to optimize an objective function. J Am Statist Assoc. 1963;58(301):236-244. http:// dx.doi.org/10.2307/2282967

49. Hill MO. Reciprocal averaging: an eigenvector method of ordination. J Ecol. 1973;61(1):237-249. http://dx.doi. org/10.2307/2258931

50. Wildi O, Orlóci L. Numerical exploration of community patterns: a guide to the use of MULVA-5. 2nd ed. Hague: SPB Academic; 1996.

51. Nei M, Li WH. Mathematical model for studying genetic variation in terms of restriction endonucleases. PNAS. 1979;76(10):5269-5273. http://dx.doi.org/10.1073/ pnas.76.10.5269

52. Buntjer JB. Phylogenetic Computer Tools ver. 1.3. Netherlands: Wageningen University; 1997.

53. Felsenstein J. PHYLIP (Phylogeny Inference Package) ver. 3.67 [Internet]. 2010 [cited 2010 Jun 18]; Available from: http://evolution.genetics.washington.edu/phylip.html

54. Tamura K, Dudley J, Nei M, Kumar S. MEGA4: Molecular Evolutionary Genetics Analysis (MEGA) software version 4.0. Mol Biol Evol. 2007;24(8):1596-1599. http://dx.doi. org $/ 10.1093 / \mathrm{molbev} / \mathrm{msm} 092$

55. Excoffier L, Smouse PE, Quattro JM. Analysis of molecular variance inferred from metric distances among dna haplotypes: application to human mitochondrial DNA restriction data. Genetics. 1992;131(2):479-491.

56. Arlequin ver. 3.1. An integrated software package for population genetic analysis [Internet]. 2010 [cited 2010 Jun 18]; Available from: http://cmpg.unibe.ch/software/arlequin3

57. Raymond M, Rousset F. An exact test for population differentiation. Evolution. 1995;49(6):1280-1283. http://dx.doi. org/10.2307/2410454

58. Weir BS, Cockerham CC. Estimating F-statistics for the analysis of population structure. Evolution. 1984;38(6):1358-1370. http://dx.doi.org/10.2307/2408641

59. Tools for population genetic analyses (TFPGA) 1.3: a Windows program for the analysis of allozyme and molecular population genetic data [Internet]. 2010 [cited 2010 Jun 18]; Available from: http://www.marksgeneticsoftware. net/tfpga.htm

60. Le Cadre S, Tully T, Mazer SJ, Ferdy J-B, Moret J, Machon N. Allee effects within small populations of Aconitum napellus ssp. lusitanicum, a protected subspecies in northern France. New Phytol. 2008;179(4):1171-1182. http://dx.doi. org/10.1111/j.1469-8137.2008.02529.x

61. Wallace LE. Spatial genetic structure and frequency of interspecific hybridization in Platanthera aquilonis and P. dilatata (Orchidaceae) occurring in sympatry. Am J Bot. 2006;93(7):1001-1009. http://dx.doi.org/10.3732/ ajb.93.7.1001

62. Lande R. Genetic variation and phenotypic evolution during allopatric speciation. Am Nat. 1980;116(4):463-479. http://dx.doi.org/10.1086/283642

63. Widén B, Andersson S. Quantitative genetics of life-history and morphology in a rare plant, Senecio integrifolius. Heredity. 1993;70:503-514. http://dx.doi.org/10.1038/ hdy.1993.73

64. Frankham R. Genetics and extinction. Biol Conserv. 2005;126:131-140. http://dx.doi.org/10.1016/j. biocon.2005.05.002

65. Utelli AB, Roy BA, Baltisberger M. History can be more important than "pollination syndrome" in determining the genetic structure of plant populations: the case of Aconitum lycoctonum (Ranunculaceae). Heredity. 1999;82:574-584. http://dx.doi.org/10.1038/sj.hdy.6885070

66. Baker HG. Reproductive methods as factors in speciation in flowering plants. Cold Spring Harb Symp Quant Biol. 1959;24:177-191.

67. Hamrick JL, Linhart YB, Mitton JB. Relationships between life history characteristics and electrophoretically detectable genetic variation in plants. Annu Rev Ecol Syst. 1979;10:173-200. http://dx.doi.org/10.1146/annurev. es.10.110179.001133

68. Templeton AR. Off-site breeding of animals and implications for plant conservation. In: Falk DA, Holsinger KE, 
editors. Genetics and conservation of rare plants. New York: Oxford University Press; 1991. p. 189-194.

69. Philipp M, Nielsen LR. Reproductive ecology of Scalesia cordata (Asteraceae), an endangered species from the Galápagos Islands. Bot J Linn Soc. 2010;162:496-503. http:// dx.doi.org/10.1111/j.1095-8339.2010.01034.x

70. Fischer M, Matthies D. Effects of population size on performance in the rare plant Gentianella germanica. J Ecol. 1998;86(2):195-204. http://dx.doi. org/10.1046/j.1365-2745.1998.00246.x

71. Lande R. Genetics and demography in biological conservation. Science. 1988;241:1455-1460. http://dx.doi. org/10.1126/science.3420403

72. Reynolds J, Weir BS, Cockerham CC. Estimation of the coancestry coefficient: basis for a short-term genetic distance. Genetics. 1983;105(3):767-779.

73. Nei M, Maruyama T, Chakraborty R. The bottleneck effect and genetic variability in populations. Evolution. 1975;29(1):1-10. http://dx.doi.org/10.2307/2407137

74. Fahselt D. Is transplanting an effective means of preserving vegetation? Can J Bot. 2007;85:1007-1017. http://dx.doi. org/10.1139/B07-087
75. Huang Y, Zhang C-Q, Li D-Z. Low genetic diversity and high genetic differentiation in the critically endangered Omphalogramma souliei (Primulaceae): implications for its conservation. J Syst Evol. 2009;47:103-109. http://dx.doi. org/10.1111/j.1759-6831.2009.00008.x

76. Holl KD, Hayes GE. Challenges to introducing and managing disturbance regimes for Holocarpha macradenia, an endangered annual grassland forb. Conserv Biol. 2006;20(4):1121-1131. http://dx.doi. org/10.1111/j.1523-1739.2006.00416.x

77. Viana e Souza HA, Lovato MB. Genetic diversity and structure of the critically endangered tree Dimorphandra wilsonii and of the widespread in the Brazilian Cerrado Dimorphandra mollis: Implications for conservation. Biochem Syst Ecol. 2010;38:49-56. http://dx.doi.org/10.1016/j. bse.2009.12.038

78. López-Pujol J, Bosch M, Simon J, Blanché C. Population genetics and conservation priorities for the critically endangered island endemic Delphinium pentagynum subsp. formenteranum (Ranunculaceae). Biodiversity Conserv. 2003;12:1937-1951. http://dx.doi. org/10.1023/A:1024103714274 